\title{
Overlap Between Lean Production and Scientific Management
}

\author{
Idriz Selimović* \\ Faculty of organisation studies, Ulica Talcev 3, 8000 Novo mesto, Slovenia \\ idrizselimovic@yahoo.com \\ Mirko Markič \\ University of Primorska, Faculty of Management, Cankarjeva 5, 6000 Koper, Slovenia \\ Faculty of organization studies, Ulica talcev 3, 8000 Novo mesto, Slovenia \\ mirko.markic@guest.arnes.si
}

\begin{abstract}
:
Research question: Does the base of lean production include principles and factors of Taylor's scientific management?

Purpose: The purpose of our research was to establish the value of overlap of the principles and factors of lean organization with basic principles and factors of scientific management.

Method: We used an integrative review of technical literature of the last 20 years (from 2000 to 2020) in which the principles and factors of scientific management and lean production were described.

Results: The principles and factors of lean production predominantly contain principles and factors of scientific management (53\% of analysed contributions support the finding that the principles of lean production include principles and factors of scientific management, $29 \%$ partly support this and $18 \%$ do not).

Organization: Our conclusions will help the owners and top managers in organizations with the decisions about the induction of principles and factors of lean production.

Society: The conclusions of the research will have theoretical and practical implications for everyone who deal with induction of principles and factors of lean production from the aspect of society's sustainable development.

Originality: The original research from the field of overlap of the principles and factors of lean production and scientific management in the Republic of Slovenia.

Limitations/ further research: We conducted an integrative review of technical literature in three world bases.
\end{abstract}

Keywords: factors, company, overlap, lean production, scientific management.

\section{Introduction}

Lean organization is a philosophy and a concept of management based on waste and resource reduction which are used in the production process (the manufacture of products and performance of services (Parkes, 2016, p. 118). Chiarini (2013, p. 15) finds that the main concept not only lean organisation, but every system of legal excellence in general is based on, must be a perfect removal of losses from the business process. Kumar, Kumar \& Sultan (2014, p. 2613) claim that it is not an easy task, as the mastery of production planning and performance 
is a complicated activity, which is affected by many variables. They differ according to the activities in which the organisation functions. Due to these findings, the predominant classical managing production paradigm should increasingly redirect to lean production.

In our research we will compare the principles and factors of lean production with the classical managing organisation paradigm theory. With classical organisation theory we will limit ourselves to F.W. Taylor and his fundamental principles and factors of scientific management. Taylor's division of work, choices, training, teaching and development of the employees, cooperation among the employees and the responsibility for decision making about how the work should be done should also be strongly present in the era of information- communication society. The difference is only in the fact that manual worker was replaced by scientific worker and that Taylorism transformed into turbo-Taylorism (Ambrož \& Ovsenik, 2010, p. 105). On the other hand, some authors are expressing a considerable measure of scepticism regarding the success of the principles of lean production. Kutin (2019, December) finds out that we constantly listen about the demand of lean production, lean administration and lean whatdolknowwhat. We would be repeating something that is a synonym for Toyota Production System and rarely would we ask ourselves about its content. Hines, Taylor \& Walsh (2018, p. 16) cite that we might wrongly understand the traditional lean approach, which should be based on practices, principles, processes, tools and techniques for waste reduction. Because of this, thinking about lean organisation from the aspect of its contents through the paradigm of scientific management principles is an intellectually exciting and socially responsible business. Based on the previous conclusions, we asked our fundamental scientific question, which goes like this: Do principles and factors of lean production overlap with principles and factors of Taylor's scientific management? We will conclude the study of principles and factors of lean production with paradigms of Taylor's scientific management with a final thought about the overlap of both principles. We assume that the majority of the principles and factors of lean production are already included in Taylor's scientific management. For this purpose, we researched the technical literature and main authors from the field of lean production and scientific management. We assume that Taylor's principles sufficiently captured the work organisation in companies and throughout the history various authors assigned different terminology to these principles in order to adjust them more to the current reality. All this resulted in the emergence of concept of lean production. In the article, we were not dealing with the concepts which emerged between Taylor's scientific management and lean production. We assumed that these concepts were already described within scientific management and lean production and that they will be included in the research of overlap of these two concepts as such. The purpose of our research was to find out the level of overlap between lean production principles and factors and fundamental principles and factors of scientific management which were designed by F.W. Taylor in 1911. 


\section{Theoretical starting points}

\subsection{Principles and factors of scientific management}

Taylor's scientific management, which prevailed as a major form of work organisation in companies and other institutions in the last century, should leave the leading position to other, more contemporary organisation paradigms. New forms of organisation are emerging in the $21^{\text {st }}$ century, such as TPS (Toyota Production System), Lean Organisation, Lean Production, Six Sigma and so on. With simple comparison of the contents of scientific management and new forms of organisation, we can see that they have at least two contents in common. Firstly, they had instructors for the induction of their principles and factors into the organisations and secondly, all the organisation approaches according to Taylor followed and took advantage of the achievements of scientific management.

Giannantonio \& Hurley-Hanson (2011, p. 8) find out that the principles and factors of scientific management contributed to management practices in the $20^{\text {th }}$ century, including the specialization of tasks, production practices, analysis and formation of work places, support schemes, person's adaptation to work and production quotas and surveillance. Taylor's principles and factors should cause the following: the emergence and establishment of the study of time and movement, the standardization of work processes and equipment and the improvement of management communication systems (Charron, Harrington, Voehl \& Wiggin, 2015, p. 38).

Kulesza, Weaver \& Friedman (2011, p. 20) write that the principles and factors of scientific management remain a lasting contribution to the development of science and profession of manager. Taylor's principles and factors of scientific management are a good starting point for further search for effective organisation controlling. Taylor's book about scientific management was also a base for Drucker's concept of Management by Objectives (Short 2011, p. 44). At the core of Taylor's scientific management - his mechanism as he called it himself - in which the workers are mainly active as objects which are run by rudimentary motives, is the performance of precisely created recurring tasks. Taylor also highlighted that around the mechanism there had to be an atmosphere of friendship, honesty and cooperation (Derksen, 2014, p. 164).

In the formation of principles and factors of scientific management, Taylor originated from the assumption that the problem of poor efficiency of workers and low wages could have been solved for the collective good of both workers and owners. He would achieve this with four different principles, Taylor (1967. p. 190):

- A scientific study of each movement (including the process, operation and so on.) of work, which replaces the old rule-of-thumb method.

- Systematic selection, training, education and development of every workman individually.

- Honest cooperation between workers in order to ensure that the work can be done in the best possible way. 
- Managers should carry the responsibility of deciding about how the work should be done, while the workmen carry the responsibility of getting the work done.

His main assumption was that for a certain amount of work there is only one best way to perform it. Ott in Shafritz (2001, p. 31) say that the organisations assumed that these methods existed and should have been discovered with careful scientific research and analyses. The principles and factors of scientific management were later taken over by Ford and he improved them with the introduction of the assembly line. The introduction of tayloristically-scientific work organisation in automotive industry and its fusion with Fordism should represent the most progressive form of capitalistic rationalisation of work process in the $20^{\text {th }}$ century. It was not until the end of the 1960s and the beginning of the 1970s that this productive model - now structurally endangered - started to show signs of exhaustion (Budgen, Edwards, Linden \& Thomas 2013, p. 23).

\subsection{Principles and factors of lean production}

Krafcik was the first one to use the term lean in context which it has today in Sloam Management Review magazine in the article Triumph of Lean Production Systems (Holland, 2019, December). In the late 1980s, James Womack, the founder of Lean Enterprise Institute and the author of Lean Thinking and The Machine that Changed the World, significantly contributed to the further popularisation and final enforcement of the term lean production, from which the term lean organisation later developed. He was the leader of a research group, which created the term lean organisation in order to describe the Toyota concept. Womack, Jones \& Roos state that lean production is lean because it consumes less in comparison to mass production: less human effort, less production space, less investments into tools, less engineers' working hours for the development of new product and so on (Womack, Jones \& Roos, 1990, p. 13).

The vital fields which lean organisations cope with are how to please their customers and how to abolish all the losses in the production process. The responsibility for the achievement of excellent results in these two main areas rearranges itself and starts from the bottom up. Unterlechner, Meško Štok in Markič (2009, p. 144) define that a messy workspace and habitual inefficiency are the two main reasons for the emergence of waste in modern production processes. Both reasons for waste are most often the main point of kaizen workshops with which these wastes are abolished. Wittrock (2015, p. 95) claims that the main principles of being lean are the components of Japanese culture and that because of this finding the transportation of principles of lean production to other cultures is not easy. Schmidt (2011, p. 83) attaches to this saying that the understanding of principles of lean production and not accepting methods and principles is vital in the introduction of principles of lean production into organisation. In the following step it is crucial to evaluate which parts can be accepted and adapted to the circumstances and most importantly, what could be improved. In the literature, five principles of lean organisation are listed, Bateman, Esain, Massey, Rich, \& Samuel (2006, p. 16-17): the definition of value from the customer's point of view, map the value stream and eliminate all 
the waste from this stream, create the flow of materials and information without any distractions, Pull production system- producing only what the customer needs and seeking the perfection. The organisations use several tools for the induction of principles of lean organisation and functioning according to them. We will list only some of them:

- $5 S$ is one of the most common lean manufacturing tools which are recommended by the experts for usage. The purpose of $5 \mathrm{~S}$ is the organisation and management by avoiding all the waste and loss which originate from a disorganised work environment. The basic aim of $5 \mathrm{~S}$ is to establish a higher level of culture and efficiency at the workplace. It consists of 5 phases: sort (Seiri), set in order (Seiton), shine (Seiso), standardize (Seiketsu) and sustain (Shitusuke). Charron, Harrington, Voehl, in Wiggin (2015, p. 255), Chiarini (2013, p. 83) and Nicholas (2018, p. 88) describe 5S as a method which ensures the establishment and maintenance of cleanliness of workspace and also enables the productivity growth, improving the quality, security and induction of fundamental principles of visual control.

- Kaizien is a system of constant process improvements which we reach with simple steps. It is preformed constantly. It means adding the value and lowering waste in the whole flow of value. Chiarini (2013, p. 64) describes the activities of kaizen workshop as group activities which strive for quick reduction of waste in a specific field. The pace of activity is the main factor which decorates the kaizen workshop and it is its key to success.

- OEE Overall Equipment Effectiveness is a lean tool which is reasonably used in halfatomised and atomised work processes. Charron, Harrington, Voehl, in Wiggin (2015, p. 260) say that with this tool we measure the equipment efficiency, its availability and quality.

- SMED Single Minute Exchange of Dies The changes of tools and settings of the machine do not represent added value, so it is not necessary to lower them to the lowest measure possible. The author of SMED method, Shingo (1985, p. XIX) says that it is impossible to replace every tool under ten minutes, but it is still an aim of all the tool replacements. The practice shows that it is possible to reach it in surprisingly many cases.

- Production levelling (Heijunka) is a technique for an equal loading of production, which is performed with the help of quantitative methods like: moving average, single exponential levelling and double and triple levelling.

The authors warn that carefulness is required with lean tool selection. Thus, Marksberry (2013, p. 1) says that the selection of lean tools is a dangerous doing and he compares the co-dependence of organisations with gardening. As it is impossible to successfully transplant a plant if the soil and environment are not the same, the transplantations of the tools from one company to the other is not possible if the two companies do not have the same culture, are not of the same size, are in different sectors and so on. Lewandowski (2014, p. 2, 32) warns about the finding that every company has its own organisation culture. It is important to consider this with the selection of a suitable tool for a certain organisation. The tool should be suited for the culture of the organisation and the collection of products or services. Some tools are universal and the others not so much. But with all this, the experts for lean production do not advise any expectations about the results being quick. 


\subsection{Overlap of lean production and scientific management}

In the article, we derive from the assumption that there is a predominant overlap of principles and factors of lean production and principles and factors of Taylor's scientific management. Charron, Harrington, Voehl \& Wiggin (2015, p. 66) see this while treating lean production as a more improved version of endeavours for higher production which should be based on other authors such as Taylor or Ford. Their false assumptions are eliminated. The comparison of overlap of Taylor's scientific management and lean production is impossible when comparing Taylor's original work Scientific Management and for instance Liker's The Toyota Way. With every single Toyota's principle and factor we would establish a suitable principle and factor from Taylor's Scientific Management. It should be necessary to interpret him in terms of what would Taylor change in every single principle and factor of his, if he knew what for example Taiichi, Ohno, Liker, Womack and others did. We could also turn the comparison upside down and, for example, for each of Taylor's principles and factors of scientific management establish which Toyota principles and factors he influenced or devised. Thus, Evangelopoulos (2011, p. 71) represents the pyramid of discourse about Taylorism. The author represents an intellectual area of practices, ideas and philosophies, which were launched by Taylor and indicates that Taylor's initial work from 1911 is still very important. Rawlinson in Wells (1996, p. 194-195) say that Shingo was a devoted follower of Taylor's work and usage of principles in the industrial engineering at Toyota, which greatly impacted Shingo's way of thinking and the production organisation. Likert (2004, p. 158) lists an example of a joint factory, built in California by Toyota and General Motors, where the workmen follow very detailed standardized procedures, but there are many group leaders and a clearly set up hierarchy. Time, expenses, quality and security were planned in detail. In NUMMI (acronym for Toyota and General Motors joint company) they had prevailing characteristics of bureaucratic and mechanic organisation which overlaps with endeavours of Taylor's scientific management. Tang (2017, p. 119) also gave an indirect connection between principles and factors of lean production in Taylor's scientific management. Tang (ibid, p. 119) explained every single Taylor's principle and factors of scientific management from the point of view of modern organisation bases. The first principle should be used with the measuring of knowledge production (Jones \& Womack 2003). Total Quality Management (TQM) should be applied in the selection of co-workers in the postmodern era (Daniel, 1995). The scientific co-worker selection should be based on co-workers' flexibility to perform a different kind of work (polyvalence) and not preforming only one task. The usage of principles and factors of education and development of workmen would mean an integration of employees into decision-making. The principle and factors should develop for the authorization of the co-workers and the domination over them (Clegg, 1990). The fourth principle and factors should exist in team work in postmodern organisations. Ribeiro (2015, p. 77) talks about the synthesis of Taylorism, Fordism and Toyotism.

\subsection{Principles and factors of scientific management in lean production}

- $5 S$ - (Seiri- sort, Seiton- set in order, Seiso- shine, Seiketsu- standardize, Shitsuke- sustain) Principle and factors of lean production for an organized workspace 
In his work, Shop Management, Taylor (1967, p. 83) recommends that every worker keeps his machine clean and oiled. A written document which the workers signed (in order to confirm the performance of machine examination on a particular day because the majority of the workers were illiterate) probably did not follow Taylor's recommendations about the maintenance of machine cleanliness.

- Total Productive Management (TPM) a tool for the boost of machine efficiency and total maintenance management and Single minute exchange of dies (SMED), a tool for the reduction of tool change times.

Taylor (1967, p. 227-228) also tested the capability of the machines in industrial plants. The evolution of the skills and science of cutting metal lasted for 26 years with occasional breaks. Between 30000 and 50000 experiments were performed altogether. We can recognize the SMED method in Taylor's description of the change of drive belt. The experts tackled with measurement of time for individual phases of production process.

- The analysis of value stream

Taylor (1967, p. 94) explains the function of planning department in scientific management as crucial for a sequence of operations. In the case of a well-planned flowchart, an even process is guaranteed. It is necessary to create a perfect analysis of the sequence of operations, which will be conducted on individual pieces (determine the exact stream through the process, which must be passed over every single part of the machine). Taylor (1967, p. 243) also mentions the system of determining the movement of products through the production, which is comparable to the following of the stream of value formation.

- $\quad$ Standardized work

Standardized work is one of the principles and factors of lean organisation which completely overlaps with principles and factors of Taylor's scientific management. Corbacioglu (2017. p. 81) says that the connection between productivity and the way in which workers complete a certain task is evident from the case of worker Schmidt. The managers need to find the best method for every task with the help of researchers and make sure that the task for every kind of work is done properly.

- Kaizen, the continual improvement process

The continual development and improvement were some of the components of factors in Taylor's scientific management. Taylor (1967, p. 242) suggests the worker should be stimulated in order to suggest any improvements, regardless of whether it is an improvement on the tools or the process. Managers should closely analyse the suggestion and conduct a series of experiments in order to get to know its value. If the new suggestion is better than the old one, it should be introduced as a standard into the organisation unity as a whole. The workers which hand over such a suggestion for improvement are entitled to a money prize and a recognition award for endeavours. 


\section{- Visual management}

Visualisation of results of the process is an important principle and factor with which we signal the employees how well their job is being done. In lean organisation we choose a certain collection of KPIs (Key Performance Indexes) and visualize them so they are accessible and visible to all the employees. Taylor (1967, p. 289-290) explains visualisation management with the help of two sheets of paper in different colours (white or yellow). In case that both sheets were white, the worker knew that everything was alright. If one of them was yellow, it meant that his results from the previous day were not satisfying. The worker knew that the supervisor would visit him if he had found yellow sheets in his closet for three days in a row. In the previous chapter we presented the basic theoretical principles and factors of scientific management, principles and factors of lean production and overlap of lean production and scientific management and principles and factors of scientific management in lean production. The aim of our research was to establish the value of overlap of the principles and factors in lean production and basic principles and factors in scientific management.

\section{Method}

In the empiric part of the research the author of this article used an integrative overview of literature from academic databases from the field of lean production and Taylor's scientific management. On the integrative examination of the literature the author of this article based a research question which has not yet been asked, but it offers a new perspective over the already known problem, Torraco (2016, p. 19). The author of this article formed hypothesis H1 based on the previous theoretical conclusions H1: The overlap between lean production and Taylor's scientific management is more than $50 \%$. The author of this article included technical literature in searching which referred to production organisations (production and service organisations) and chose technical literature which included descriptions of principles and factors of Taylor's scientific management and lean production. Starting choice of the classics from the field of scientific management (Taylor, 1967) and lean production (Liker, 2004 \& Womack, 2003) was crucial for the better depiction of both designs and other authors in the last 20 years (the period between 2000 and 2019). A graphical representation of our research is shown Figure 1. 


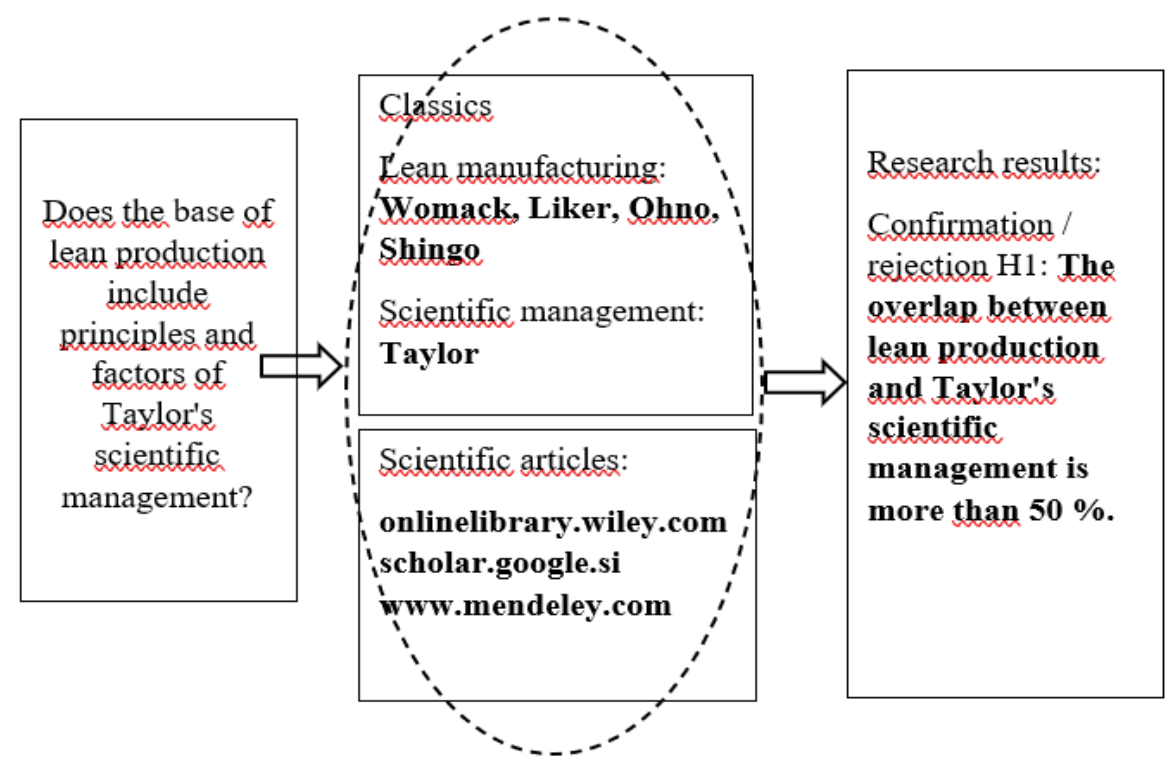

Figure 1. Research model

The technical literature the author of this article used was chosen after the examination of the bases of scientific articles in Wiley Library (onlinelibrary.wiley.com), web browser Google Scholar (scholar.google.si) and tool browser for citation editing Mendeley desktop (www.mendeley.com). Key words which the author of this article used in the search for material were: fact fiction frederick $\mathrm{w}$ taylor, lean manufacturing implementation, frederick w taylor myth and reality, taylor lean manufacturing and frederick taylor, which are represented in table 1.

Table 1. Results of the literature review by keywords

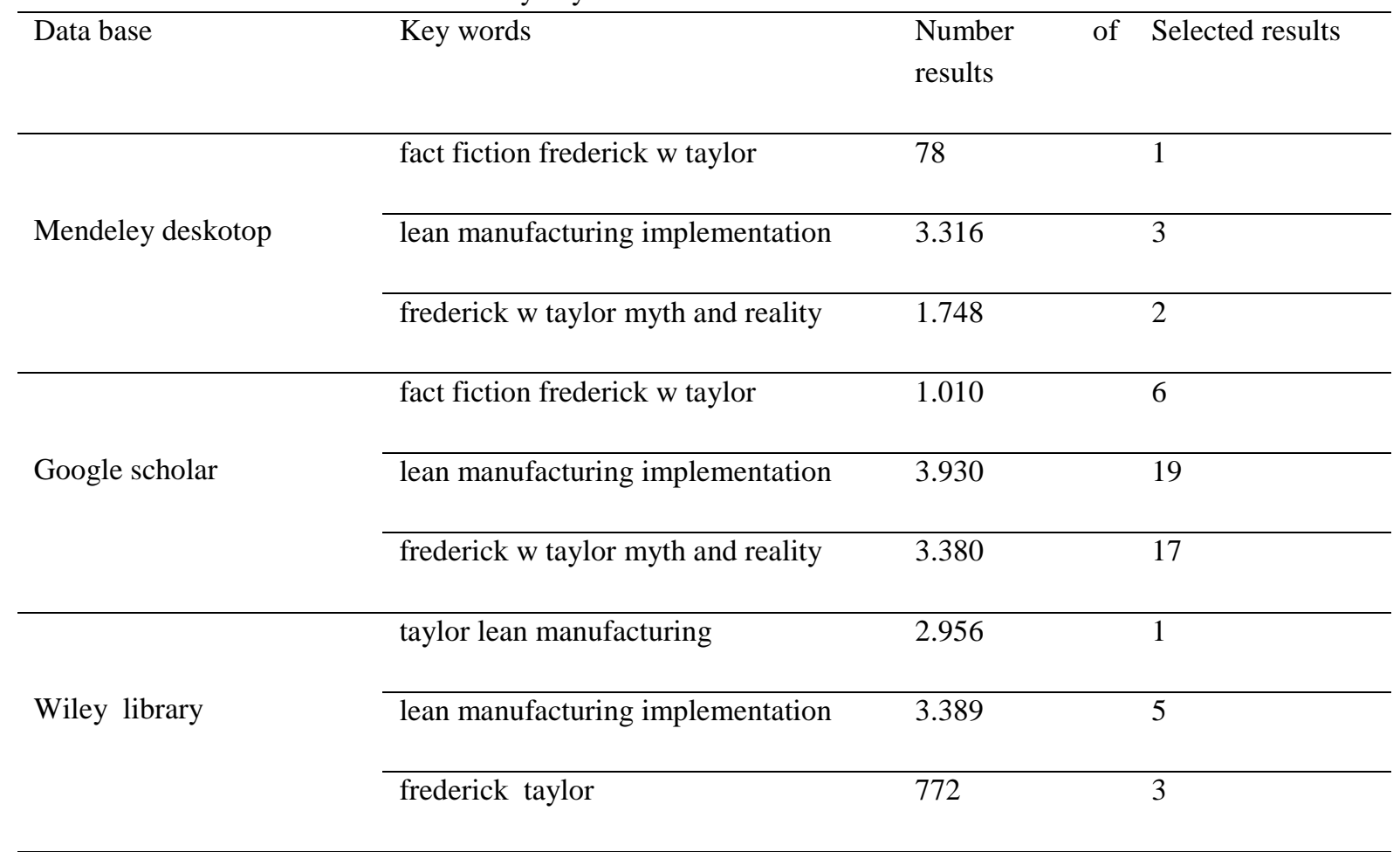


For the decision about whether to include or exclude the results in further processing, the author of this article took into consideration the content adjustment to our research question: Does the base of lean production include principles and factors of Taylor's scientific management? In the research, the author of this article included articles which either compared scientific management and lean production or described the principles of scientific management and lean production in detail. The process of reduction of studied material is shown in Figure 2. Firstly, the author of this article evaluated whether the results (there was 20759 of them) covered the field we were researching, based on their titles. The author of this article chose 321 titles whose abstracts we read and decided whether to keep or discard the article. Based on the content of matching the abstracts we limited ourselves to a closer overlook of 58 bibliographic units and 49 of them were included when looking for an answer to our research question.

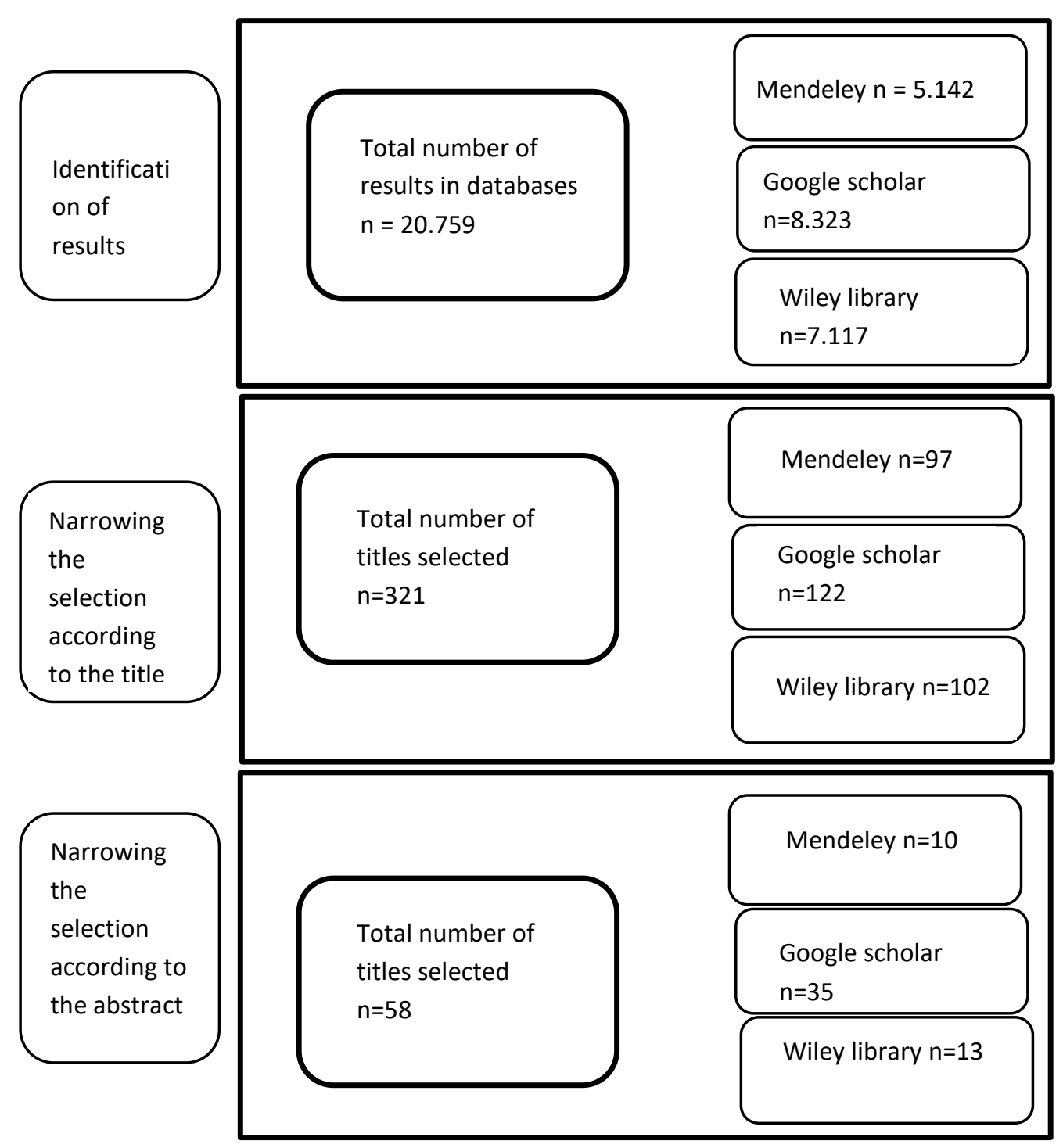

Figure 2. The process of reduction of studied material 


\section{Results}

In table 2 we listed the literature and authors the author of this article used when searching for an answer to our research question: Does the base of lean production include principles and factors of Taylor's scientific management? The author of this article showed our estimation of author of the analysed publication based on our scientific question. In the second column of the table there are names of authors, in the third there is a title of the work we analysed and in the fourth the evaluation of author's attitude towards our research question (true, partly true, not true). In the end, we created a graph and figure which show how our evaluations are arranged (Table 2.), (Figures 2.). The analysed article was marked with grade true if the author lists that the principles and factors of lean production originate from scientific management. With grade partly true we marked the articles where author's point of view about the principles and factors of lean production overlapping the ones of scientific management is not entirely clear. The grade not true was given to all the articles where authors do not mention the influence of scientific management when describing the history of lean production.

Table 2. The evaluations of the attitude of authors of analysed publications according to our scientific question, whether the concept of lean production includes the principles of scientific management.

\begin{tabular}{|c|c|c|c|}
\hline Ord N. & Autor & Publication & $\begin{array}{l}\text { Does the base of lean } \\
\text { production include } \\
\text { principles and factors of } \\
\text { Taylor's scientific } \\
\text { management? }\end{array}$ \\
\hline 1 & $\begin{array}{l}\text { Adams, D.E., Smith, T., \& } \\
\text { Urick, M.J,(2017) }\end{array}$ & $\begin{array}{l}\text { Taylorism and Operational Excellence Improving on } \\
\text { the "One Best Way" }\end{array}$ & True \\
\hline 2 & $\begin{array}{l}\text { Hines P., Holweg M., \& Rich N. } \\
\text { (2004) }\end{array}$ & $\begin{array}{l}\text { Learning to evolve A review of contemporary lean } \\
\text { thinking }\end{array}$ & Partly true \\
\hline 3 & Pruijt H. (2003) & Teams between Neo-Taylorism and Anti-Taylorism & True \\
\hline 4 & Hop W. J. (2018) & $\begin{array}{l}\text { Positive lean: merging the science of efficiency with } \\
\text { the psychology of work }\end{array}$ & Partly true \\
\hline 5 & $\begin{array}{c}\text { Vijai, J. P., Somayaji, G. S. R., } \\
\text { Swamy, R. J. R., \& Aital, P. } \\
(2017)\end{array}$ & $\begin{array}{l}\text { Relevance of F.W. Taylor's principles to modern } \\
\text { shop-floor practices: a benchmarking work study }\end{array}$ & True \\
\hline 6 & Mtar, K., \& Smondel, A.(2019) & $\begin{array}{l}\text { JIT inventory control and manufacturing SME } \\
\text { performance }\end{array}$ & Not true \\
\hline 7 & Lubnina, A. A., \& all (2018) & $\begin{array}{l}\text { Innovative strategy for improving the } \\
\text { efficiency of industrial enterprises } \\
\text { management }\end{array}$ & True \\
\hline 8 & Palla, A. K., \& Billy, I. (2018) & $\begin{array}{l}\text { Scientific management: its inapplicability to } \\
\text { contemporary management challenges }\end{array}$ & Not true \\
\hline 9 & Wilson, J.(2018) & $\begin{array}{l}\text { Deconstructing the reinvention of operations } \\
\text { management }\end{array}$ & True \\
\hline 10 & Tsukamoto, W. S. (2007) & $\begin{array}{l}\text { An Institutional Economic Reconstruction of Scientific } \\
\text { Management: On the Lost Theoretical } \\
\text { Logic of Taylorism }\end{array}$ & True \\
\hline 11 & Corbacioglu, S.(2017) & $\begin{array}{l}\text { Influence of Taylorism on Deming'S Quality } \\
\text { Management }\end{array}$ & True \\
\hline 12 & Turan, H. (2015) & $\begin{array}{l}\text { Taylor's "Scientific Management Principles": } \\
\text { Contemporary Issues in Personnel Selection Period }\end{array}$ & Not true \\
\hline 13 & Kemp, L. J. (2013) & $\begin{array}{l}\text { Modern to postmodern management: developments in } \\
\text { scientific management }\end{array}$ & True \\
\hline
\end{tabular}


Izzivi prihodnosti / Challenges of the Future,

November 2020, leto / year 5, številka / number 4, str. / pp. 234-253.

»continued«

\begin{tabular}{|c|c|c|c|}
\hline 14 & Derksen, M. (2014) & $\begin{array}{l}\text { Turning men into machines? scientific management, } \\
\text { industrial psychology, and the "human factor" }\end{array}$ & True \\
\hline 15 & $\begin{array}{c}\text { Rask, K } \\
\text { Johansson, J. (2008) }\end{array}$ & $\begin{array}{l}\text { Similarities and Differences between Lean Production, } \\
\text { Tayloristic and Socio-Technical Systems Revealed in } \\
\text { the Methodology Characteristics Map }\end{array}$ & Partly true \\
\hline 16 & Emiliani, M.L. (2006) & Origins of lean management in America & True \\
\hline 17 & Evangelopoulos, N. (2011) & $\begin{array}{l}\text { Citing Taylor:Tracing Taylorism's Technical and } \\
\text { Sociotechnical Duality through Latent Semantic } \\
\text { Analysis }\end{array}$ & True \\
\hline 18 & Paxton J. (2011) & $\begin{array}{l}\text { Taylor's Unsung Contribution: Making } \\
\text { Interchangeable Parts Practical }\end{array}$ & True \\
\hline 19 & $\begin{array}{l}\text { Giannantonio, C.M., \& Hurley- } \\
\text { Hanson, A.E. (2011) }\end{array}$ & $\begin{array}{l}\text { Frederick Winslow Taylor: Reflections on the } \\
\text { Relevance of The Principles of Scientific Management } \\
100 \text { Years Later }\end{array}$ & True \\
\hline 20 & Handel, M. (2014) & $\begin{array}{l}\text { Theories of lean management: An empirical } \\
\text { evaluation. }\end{array}$ & Not true \\
\hline 21 & Hernaus, T. (2017) & Teorija organizacije & Partly true \\
\hline 22 & Wren,D. A. (2011) & $\begin{array}{l}\text { The Centennial of Frederick W. Taylor's The } \\
\text { Principles of Scientific Management: A Retrospective } \\
\text { Commentary }\end{array}$ & Partly true \\
\hline 23 & $\begin{array}{l}\text { Kulesza, M.G., Weaver, P.Q., \& } \\
\text { Friedman, S. (2011) }\end{array}$ & $\begin{array}{l}\text { Frederick W. Taylor's presence in } 21 \text { st century } \\
\text { management accounting systems and work process } \\
\text { theories }\end{array}$ & True \\
\hline 24 & Kutin, M. (2019) & Vitka organizacija in kriza ali cesarjeva nova oblačila & True \\
\hline 25 & Melton, T. (2005) & $\begin{array}{l}\text { The Benefits of Lean Manufacturing } \\
\text { What Lean Thinking has to Offer the Process } \\
\text { Industries }\end{array}$ & Not true \\
\hline 26 & Liker, J. (2004) & $\begin{array}{l}\text { The Toyota Way - } 14 \text { management principles the } \\
\text { world's greatest manufacturer }\end{array}$ & Partly true \\
\hline 27 & Parks, Charles M. (2003) & $\begin{array}{l}\text { The bare necessities of lean: } 10 \text { things your lean guru } \\
\text { may not tell you about making just-in-time work. }\end{array}$ & Partly true \\
\hline 28 & $\begin{array}{l}\text { Iuga, M., V., \& Kifor, Claudiu, } \\
\text { V., (2013) }\end{array}$ & Lean manufacturing: the when, the where, the who & True \\
\hline 29 & Balle, F., \& Balle, M. (2020) & Lean nor Sigma & True \\
\hline 30 & $\begin{array}{c}\text { Nepal, P.B.,Yadav, O.P., } \\
\text { Rahaman, M., \& Lal, V. (2017) }\end{array}$ & $\begin{array}{l}\text { Lean Implementation and Organizational } \\
\text { Transformation }\end{array}$ & Not true \\
\hline 31 & Brennan, L. L (2011) & The Scientific Management of Information Overload & Partly true \\
\hline 32 & Ohno T. (1988) & Workplace Management & Partly true \\
\hline 33 & Parkes, A. (2016) & Lean Management Genesis & Partly true \\
\hline 34 & Pech, M., \& Vaneček, D. (2018) & $\begin{array}{l}\text { Methods of Lean Production to Improve Quality in } \\
\text { Manufacturing }\end{array}$ & True \\
\hline 35 & $\begin{array}{l}\text { Stentoft Arlbjørn, J., \& Vagn } \\
\text { Freytag, P. (2013) }\end{array}$ & $\begin{array}{l}\text { Evidence of lean: a review of international peer- } \\
\text { reviewed journal articles }\end{array}$ & True \\
\hline 36 & $\begin{array}{l}\text { Johansson, J., \& Abrahamsson, } \\
\text { L. (2009) }\end{array}$ & $\begin{array}{l}\text { The good work - A Swedish trade union vision in the } \\
\text { shadow of lean production }\end{array}$ & True \\
\hline 37 & Ribeiro, A.F. (2015) & Taylorismo, fordismo e toyotismo & Partly true \\
\hline 38 & Smith, S. (2014) & Muda, Muri and Mura & True \\
\hline
\end{tabular}


Izzivi prihodnosti / Challenges of the Future,

November 2020, leto / year 5, številka / number 4, str. / pp. 234-253.

»continued «

39

Teehan, R., \& Tucker, W. (2010) A simplified lean method to capture customer voice.

Not true

\begin{tabular}{|c|c|c|c|}
\hline 40 & Short, J.C. (2011) & $\begin{array}{l}\text { The Debate Goes On! A Graphic Portrayal Of The } \\
\text { Sinclair-Taylor Editorial Dialogue }\end{array}$ & True \\
\hline 41 & $\begin{array}{c}\text { Karim, A., \& Arif-Uz-Zaman, K. } \\
\text { (2013) }\end{array}$ & $\begin{array}{l}\text { A methodology for effective implementation of lean } \\
\text { strategies and its performance evaluation in } \\
\text { manufacturing organizations }\end{array}$ & True \\
\hline 42 & Tang, H. (2017) & The Implications of Taylorism... & True \\
\hline 43 & Howison, J. D. (2009) & $\begin{array}{l}\text { A Tough "Cell": Implementing Lean Production at } \\
\text { Toledo Jeep }\end{array}$ & Partly true \\
\hline 44 & $\begin{array}{l}\text { Koskela, L. J., Sacks, R., \& } \\
\text { Rooke, J. A. (2020) }\end{array}$ & A brief history of the concept of waste in production. & Partly true \\
\hline 45 & $\begin{array}{l}\text { Hummels, H., \& de Leede, J. } \\
\text { (2000) }\end{array}$ & $\begin{array}{l}\text { Teamwork and Morality: } \\
\text { Comparing Lean Production } \\
\text { and Sociotechnology }\end{array}$ & Not true \\
\hline 46 & $\begin{array}{l}\text { Womack J.P., \& Jones, D.T } \\
(2003)\end{array}$ & Lean thinking & Partly true \\
\hline 47 & Wittrock, C. (2015) & $\begin{array}{l}\text { Reembedding Lean: The Japanese Cultural and } \\
\text { Religious Context of a World Changing Management } \\
\text { Concept }\end{array}$ & Not true \\
\hline 48 & Zuffo, R.G. (2011) & $\begin{array}{l}\text { Taylor is Dead, Hurray Taylor!The "Human Factor" in } \\
\text { Scientific Management: Between Ethics, }\end{array}$ & True \\
\hline 49 & Smith, C., \& Vidal, M. (2019) & $\begin{array}{l}\text { The lean labour process: Global diffusion, societal } \\
\text { effects, contradictory implementation }\end{array}$ & True \\
\hline
\end{tabular}

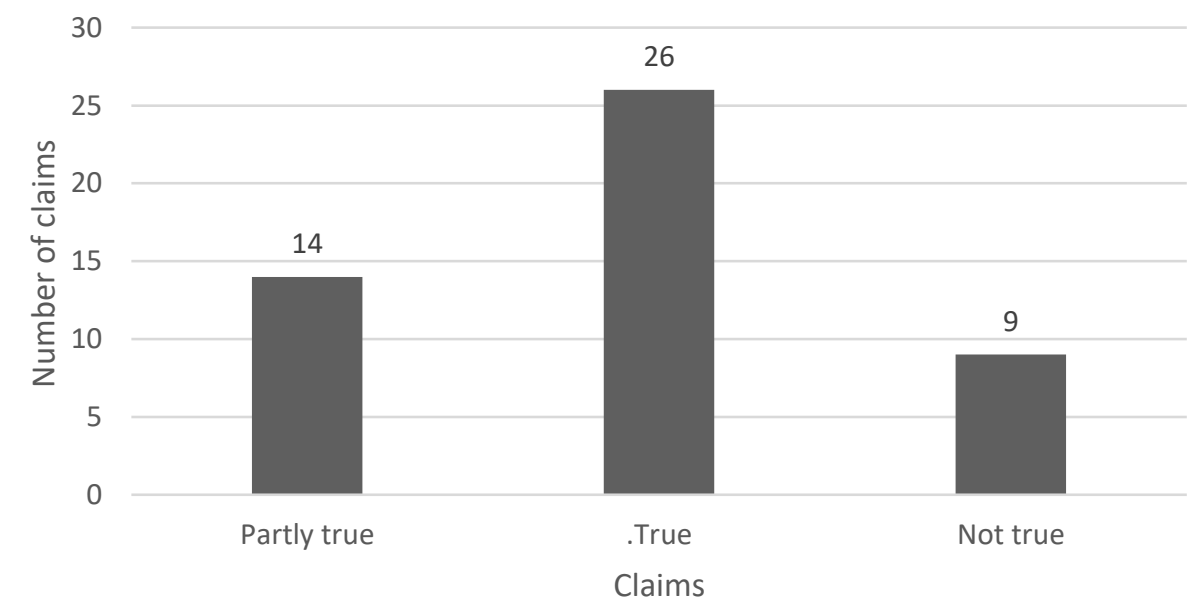

Figure 2. The results of the research about the integration of scientific management into the concept of lean production

\section{Discussion}

When analysing the articles, we included in the research we were seeking an answer to the research question: Does the foundation of lean production include principles of scientific management? We got an answer by individually evaluating authors' attitudes towards our research question. We concluded that 26 of the authors confirmed that the principles of lean production do include the principles of scientific management, 14 of them partly support this and 9 of them do not agree. The majority of the authors we analysed find out that the 
contribution of scientific management to the development of organisational science is enormous. The differences among the authors occur in the following questions:

- How big the historical contribution of scientific management to the organisation science actually is?

- Various authors interpret Taylor's principles of scientific management differently; from the inhumane treatment of workers to being the pioneer of humane relationship towards the employees (Derksen, Tang).

- Some authors claim that lean organisation has roots in scientific management and that there are similarities between them, whereas others strongly deny this (Ott \& Shafritz, Budgen, Edwards, Linden \& Thomas, Charron, Harrington, Voehl \& Wiggin, Corbacioglu).

- Taylor is not credited for his scientific approach (there is no science in observing worker Schmidt shifting iron with a spade), but others greatly appreciate his approach (Giannantonio \& Hurley-Hanson, Kulesza, Weaver \& Friedman, Short, Charron, Harrington, Voehl \& Wiggin, Rawlinson in Wells).

- Taylor's impact on the modern organisation; in individual environments and other institutions Taylor' way of managing the organisations prevails, while others speak about the extinction of his methods (Evangelopoulos, Liker, Ribeiro).

- Based on the analysed articles we confirmed hypothesis H1: The overlap between lean production and Taylor's scientific management is more than $50 \%$. From the table it is evident that the overlap between lean production and Taylor's scientific management is $53 \%$. We did not come across any author specially searching for an answer to the question Does the foundation of lean production include the principles and factors of Taylor's scientific management? or this kind of question being partly or without further explanation debated as a part of the discussion of some other issue. We would like to point out the big differences between the times when Taylor's scientific management was in making and times when the concept of lean production was in development. The social conditions were different and the law did not protect the worker as it does today, the majority of the employees were illiterate, the production workers knew the work process better that the managers, the market was not demanding and there was a lack of goods in general. Our opinion is that Taylor would also have his own concept of scientific management equal to what we call today the concept of lean production, if we assume that the conditions he lived in resembled the ones we have today. The difference would be merely in the naming of the tools and methods. Some lean tools like pull system were useless in Taylor's times, as the market was predominated by shortage. The introduction of pull system would be a pure lean production waste in Taylor's times and without any added value. Similar is in force today, the foundation of lean production inside its concept should not include anything what does not bring an added value. It does not include what could turn out to be very useful in for example 2050. 


\section{Conclusion}

The main aim of our research was to establish the stage of overlap of the principles of lean production and the principles of scientific management which were conceived by F. W. Taylor in 1911. In the empirical part of the research we used an integrative overlook of technical literature from the field of lean production and Taylor's scientific management. The technical literature that we used was chosen after the examination of bases of scientific articles in Wiley library (onlinelibrary.wiley.com), online browser Google Scholar (scholar.google.si) and tool browser for citation editing Mendeley desktop (www.mendeley.com). Among 20759 results we chose 321 titles, read their abstracts and decided whether to keep or discard the article. According to the content of the abstract we limited the examination to a closer overlook of 58 bibliographic units and 49 of them were later included in answering to our research question. We concluded that the principles and factors of lean production prevailingly include the principles and factors of scientific management (53\% of the analysed articles support the finding that the principles and factors of lean production include the principles and factors of scientific management, $29 \%$ partly support it and $18 \%$ do not support it at all).

The contribution of findings from the articles to the management science and profession is theoretical, empirically-investigative and practical. In the theoretical part of the research, we gained and presented in one place new knowledge about the factors of lean production and scientific management which enable the creation of conceptual model and forming scientific question and hypotheses. In the empirical part of the research, we came to new knowledge about the level of overlap of principles and factors of lean production and basic principles and factors of scientific management with the help of the analysis of the articles. The overlap of principles and factors of lean production and principles and factors of scientific management is more than $50 \%$. The overlap of the principles and factors of lean production with the principles and factors of scientific management will also have practical implications for the economic companies in the Republic of Slovenia and beyond. Our findings will help the owners and top managers with the decisions regarding the principles and factors of lean production.

While conducting the research we faced individual assumptions and restrictions. We originated from the assumption that in domestic and foreign researches about the overlap of principles and factors of lean production and basic principles and factors of scientific management so far, the study with such point of view has not yet been conducted. We assumed that the function of production is among the fundamental functions in every company and institution and is mostly inconsistent with other fundamental functions like marketing or financing. The research was limited to the selection of publicly accessible bases of scientific articles: Wiley Library, Google Scholar and using Mendeley desktop. In the analysis of the overlap of the principles and factors of lean production and the principles and factors of scientific management we did not study the impact of the overlap of these principles and the key performance indicators of production processes like for example OEE, 5S, TPM, A3 and so on. 
The research from the field of overlap of the principles and factors of lean production and the fundamental principles and factors of scientific management have not been conducted yet in the Republic of Slovenia, so our results cannot be compared to any similar or comparable one. The results we got from the integrative examination of the technical literature could be a good base for a possible further research from various aspects, theoretical as well as methodological. Further research could be conducted by examining the technical literature and other publicly accessible scientific articles like for example JStor, Emerald, Ebsco, Proquest, Springer and so on. Further on, the research could be substantively continued in the course of establishing the impact of factors of lean production and scientific management on individual or composite indicators of successfulness of the (business, technological or comprehensive) organisation.

\section{ACKNOWLEDGEMENT}

The article was written as part of project no. P5-0049, co-financed from the state budget by Slovenian Research Agency.

\section{References}

1. Adams, D. E., Smith T. \& Urick M. J. (2017). Taylorism and Operational Excellence Improving on the "One Best Way". Journal of Leadership and Management, 9(10), 7-21.

2. Ambrož, M., \& Ovsenik, M. (2010) Celovitost in neznatnost organizacije. Ljubljana: Inštitut za management.

3. Balle, F., \& Balle, M. (Pridobljeno 19.04.2020.) Lean nor Sigma. https://www.lean.org/Downloads/leanorsigma.pdf

4. Bateman, N., Esain, A., Massey, L., Rich, N., \& Samuel. D. (2006). Lean Evolution:Lessons from the Workplace. New York: Cambridge Univesitiy Press.

5. Brennan, L.L. (2011). The Scientific Management of Information Overload. Journal of Business and Management, 17(1), 121-134.

6. Budgen, S., Edwards, S., Linden, M., \& Thomas, P. (2013). Exploring the role of lean thinking in sustainable business practice: A systematic literature review. Historical Materialism Book Series. Leiden: Koninklijke Brill NV

7. Charron, R., Harrington, H. J., Voehl, F., \& Wiggin, H. (2015). The lean management systems handbook. Boca Raton: Taylor \& Francis Group.

8. Chiarini, A. (2013). Lean Organization: from the Tools of the Toyota Production System to Lean Office. Milan: Springer.

9. Corbacioglu, S. (2017). Influence of Taylorism on Deming'S Quality Management. Sarajevo Journal of Social Sciences Inquiry, 2(2), 77-78. doi: 10.21533/isjss.v2i2.85

10. Emiliani, M.L. (2006). Origins of lean management in America. Journal of Management History, 12(2), 167-184. doi: 10.1108/13552520610654069.

11. Evangelopoulos, N. (2011). Citing Taylor: Tracing Taylorism's Technical and Sociotechnical Duality through Latent Semantic Analysis. Journal of Business \& Management, 17(1), 57-72.

12. Derksen, M. (2014). Turning men into machines? scientific management, industrial psychology, and the "human factor". Journal ofthe History ofthe Behavioral Sciences, 50(2), 148-165. doi: $10.1002 / \mathrm{jhbs}$

13. Giannantonio, C. M. \& Hurley-Hanson, A. E. (2011) Frederick Winslow Taylor: Reflections on the Relevance of The Principles of Scientific Management 100 Years Later. Journal of Business \& Management, 17(1), 7-10. 
14. Handel, M. J. (2014). Theories of lean management: An empirical evaluation. Social Science Research, 44, 86-102. doi: 10.1016/j.ssresearch.2013.10.009

15. Hernaus, T. (2017). Teorije organizacije. Organizacija 26, 27-66.

16. Hines, P., Holweg, M., \& Rich, N. (2004). Learning to evolve, International Journal of Operations \& Production Management, 24(10), 994 - 1011. doi: 10.1108/00251749810239504

17. Hines, P., Taylor, D., \& Walsh, A. (2018). The Lean journey: have we got it wrong? Total Quality Management and Business Excellence, O(0), 1-18. doi: 10.1080/14783363.2018.1429258

18. Holland K. (2019, 05. december). "Lean” 25 Years Later. Pridobljeno na: https://www.leannews.com/lean-25-years-later/

19. Hop, J. W. (2018). Positive lean: merging the science of efficiency with the psychology of work. International Journal of Production Research, 56(1-2), 398-413.

20. Howison, J. D. (2009). A Tough "Cell": Implementing Lean Production at Toledo Jeep. Critical Sociology, 35(5), 689-696. doi:10.1177/0896920509337614

21. Hummels, H., \& de Leede, J. (2000). Teamwork and Morality: Comparing Lean Production and Sociotechnology. Journal of Business Ethics, 26(1), 75-88. doi:10.1023/a:1006242516664

22. Google Scholar. https://scholar.google.com/

23. Iuga, M., V., \& Kifor, Claudiu, V., (2013). Lean manufacturing: the when, the where, the who. Land Forces Academy Review, 18(4), 404-410.

24. Johansson, J., \& Abrahamsson, L. (2009). The good work - A Swedish trade union vision in the shadow of lean production. Applied Ergonomics, 40(4), 775-780. doi:10.1016/j.apergo.2008.08.001

25. Jones, D. T., \& Womack, J. P. (2003). Lean thinking: banish waste and create wealth your corporation. New York: Simon \& Schuster, Inc.

26. Karim, A., \& Arif-Uz-Zaman, K. (2013). A methodology for effective implementation of lean strategies and its performance evaluation in manufacturing organizations. Business Process Management Journal, 19(1), 169-196. doi:10.1108/14637151311294912

27. Kemp, L. J. (2013). Modern to postmodern management: developments in scientific management. Journal of Management History, 19(3), 345-361. doi:10.1108/jmh-02-2011-0005

28. Koskela, L. J., Sacks, R., \& Rooke, J. A. (pridobljeno 19.04.2020.) A brief history of the concept of waste in production. Pridobljeno na: http://usir.salford.ac.uk/23082/

29. Kulesza, M. G., Weaver, P., \& Friedman, S. (2011). Frederick W. Taylor's presence in 21st century management accounting systems and work process theories. Journal of Business \& Management, 17(1) 105-119.

30. Kumar, R., Kumar, V., \& Singh, S. (2014). Effect of Lean Principles on organizational efficiency. Applied Mechanics and Materials, 592, 2613-2618. doi: 10.4028/www.scientific.net/AMM.592594.2613

31. Kutin, M. (2019, 12. december). Vitka organizacija in kriza ali cesarjeva nova oblačila. Pridobljeno na: https://www.razgledi.net

32. Liker, J. K. (2004). The Toyota way. New york: McGraw-Hill.

33. Lewandowski, R. G. (2014). Beyond Lean Production; Emphasizing Speed and Innovation to Beath the Competition. Boca Ration, NW: Taylor \& Francis Group

34. Lubnina, A. A., Shinkevich, M. V., Ekaterina, N. Yalunina, E. N., Gaidamashko, I. V., Savderova, A. F., \& Komissarova, M. A. (2018). Innovative strategy for improving the efficiency of industrial enterprises management. Revista espacios, 39(09), 1-25.

35. Marksberry P. (2013). The modern theory production system of the Toyota. Boca Ration, NW: Taylor \& Francis Group

36. Mendeley. www.mendeley.com

37. Melton, T. (2005). The Benefits of Lean Manufacturing. Chemical Engineering Research and Design, 83(6), 662-673. doi:10.1205/cherd.04351

38. Mtar, K., \& Smondel, A. (2019). JIT inventory control and manufacturing SME performance. Human Systems Management, 38(3), 243-255. doi:10.3233/hsm-180413 
39. Nepal, P.B.,Yadav, O.P., Rahaman, M., \& Lal, V. (2017). Lean Implementation and Organizational Transformation: A Literature Review. EMJ - Engineering Management Journal, 19(1), 2-16. doi: 10.1080/10429247.2016.1263914.

40. Ohno, T. (1988). Workplace Management. Cambridge: Productivity Press

41. Ott, J. S., \& Shafritz, J. M. (2001). Classical Organization Theory. Harcourt College Publishers, Sea Harbor Drive, Orlando.

42. Parks, C. M. (2003). The bare necessities of lean: 10 things your lean guru may not tell you about making just-in-time work. Industrial Engineer, 35(8), 1-39.

43. Paxton, J. (2011). Taylor's Unsung Contribution: Making Interchangeable Parts Practical. Journal of Business and Management, 17(1): 75-83

44. Palla, A. K., \& Billy, I. (2018). Scientific management: its inapplicability to contemporary management challenges. The Business and Management Review, 9(3), 459-463

45. Parkes, A. (2016). Lean Management Genesis. Management, 19(2), 106-121. doi: 10.1515/manment-2015-0017.

46. Pech, M., \& Vaneček, D. (2018). Methods of Lean Production to Improve Quality in Manufacturing. Quality Innovation Prosperity, 22(2), 1-15. doi: 10.12776/qip.v22i2.1096

47. Pruijt H. (2003). Teams between Neo-Taylorism and Anti-Taylorism. Economic and Industrial Democracy, 24(1), 77-101.

48. Rask, K., \& Johansson, J. (2008). between Lean Production, Tayloristic and Socio-Technical Systems Revealed in the Methodology Characteristics Map. Flexible Automation and Intelligent Manufacturing, 995-1001.

49. Rawlinson, M., \& Wells, P. (1996). Taylorism, lean production and the automotive industry. Asia Pacific Business Review, 2(4), 37-41.

50. Ribeiro, A. F. (2015). Taylorismo, fordismo e toyotismo. (Taylorism, Fordism and Toyotism) Lutas Sociais, 19(35), 65-79.

51. Schmidt, S. (2011). From Hype to Ignorance - A Review of 30 Years of Lean Production, International Journal of Social, Behavioral, Educational, Economic, Business and Industrial Engineering, (5)1, 82-85

52. Shingo, S. (1985). A Revolution in Manufacturing: The SMED System. Boca Ration, NW: Taylor $\&$ Francis Group.

53. Short, J. C. (2011). The Debate Goes On! A Graphic Portrayal Of The Sinclair-Taylor Editorial Dialogue. Journal of Business \& Management, 17(1) 43-56.

54. Smith, C., \& Vidal, M. (2019). The lean labour process: Global diffusion, societal effects, contradictory implementation. Cambridge University Press. Pridobljeno: https://pure.royalholloway.ac.uk/portal/en/publications/the-lean-labour-process(8036a351-ff654e1c-830f-8a7f0df44cbe).html

55. Smith, S. (2014). Muda, Muri and Mura. ASQ Six Sigma Forum Magazine, 13(2), 36-37.

56. Stentoft Arlbjørn, J., \& Vagn Freytag, P. (2013). Evidence of lean: a review of international peerreviewed journal articles. European Business Review, 25(2), 174-205. doi:10.1108/09555341311302675

57. Taylor, F. W. (1967) Naučno upravljanje (Scientific Management). Beograd: Izdavačko preduzeće Rad.

58. Taylor, F. W. (1967) Upravljanje pogonom (Shop management). Beograd: Izdavačko preduzeće Rad.

59. Teehan, R., \& Tucker, W. (2010). A simplified lean method to capture customer voice. International Journal of Quality and Service Sciences, 2(2), 175-188. doi:10.1108/17566691011057348

60. Tsukamoto, W. S. (2007). An Institutional Economic Reconstruction of Scientifi Management: On the Lost Theoretical Logic of Taylorism. The Academy of Management Review, 32(1)105-117 
61. Tang, H. (2017). 4th International Conference on Education \& Training, Management and Humanities Science 2018 (str. 119-122). Wuhan, China: Wuchang University of Technology, Wuhan,

62. Turan, H. (2015). Taylor's "Scientific Management Principles": Contemporary Issues in Personnel Selection Period. Journal of Economics, Business and Management, 3(11), 1102-1105. doi: 10.7763/joebm.2015.v3.342

63. Wilson, J. M. (2018). Deconstructing the reinvention of operations management. Journal of Management History, 24(2), 128-155. doi:10.1108/jmh-06-2017-0028

64. Wiley. www. onlinelibrary.wiley.com

65. Wittrock, C. (2015). Reembedding Lean: The Japanese Cultural and Religious Context of a World Changing Management Concept, International Journal of Sociology, (45), 95-111. doi: 10.1080/00207659.2015.1061852

66. Womack, J. P., Jones, D., T., \& Roos D. (1990). The Machine that changed the World. New York: Rawson Associates.

67. Wren, D.A. (2011). The Centennial of Frederick W. Taylor's The Principles of Scientific Management: A Retrospective Commentary. Journal of Business and Management, 17(1): 11-22

68. Zuffo R. G. (2011). Taylor is Dead, Hurray Taylor! The "Human Factor" in Scientific Management: Between Ethics, Scientific Psychology and Common Sense. Journal of Business \& Management 17(1) 23-37.

69. Vijai, J. P., Somayaji, G. S. R., Swamy, R. J. R., \& Aital, P. (2017). Relevance of F.W. Taylor's principles to modern shop-floor practices. Benchmarking. International Journal, 24(2), 445-466. doi:10.1108/bij-02-2015-0019

70. Torraco, R. J. (2016). Writing Integrative Literature Reviews: Using the Past and Present to Explore the Future. Human Resource Development Review, 15(4), 404-428. doi: $10.1177 / 1534484316671606$

71. Unterlechner, M., Meško Štok, Z., \& Markič, M.(2009). Inoviranje, kakovost in Lean Six Sigma v proizvodnem procesu. Koper: Fakulteta za management.

$* * *$

Idriz Selimović Idriz Selimović received a master's degree from the Faculty of Organisation Studies in Novo mesto in the field of modelling organisation changes. For thirty years, he has been working in economy on different assignments. He is employed in Rotis Ltd as an assistant to production director.

Mirko Markič obtained a PhD from the Faculty of Organizational Sciences, University of Maribor in the field of organisation sciences on the topic of innovation. After twelve years of working in economy he got employed at the Faculty of Management, University of Primorska. He is a full professor in the field of management and scientific advisor and a leader or a member of 17 research projects and projects connected to economy. His bibliography includes more than 600 units from the fields of administrative and organisation sciences and public health (safety at work).

\section{Povzetek:}

\section{Sovpadanje vitke proizvodnje in znanstvenega menedžmenta}

Raziskovalno vprašanje (RV): Ali zasnova vitkega proizvajanja vsebuje načela in dejavnike Taylorjevega znanstvenega menedžmenta?

Namen: Namen naše raziskave je bil ugotoviti vrednost sovpadanja načel in dejavnikov vitkega proizvajanja s temeljnimi načeli in dejavniki znanstvenega menedžmenta. 
November 2020, leto / year 5, številka / number 4, str. / pp. 234-253.

Metoda: Uporabili smo integrativni pregled strokovne literature za preteklih 20 let (od 2000-2020) $\mathrm{v}$ kateri so bila opisana načela in dejavniki znanstvenega managementa in vitkega proizvajanja.

Rezultati: Načela in dejavniki vitkega proizvajanja prevladujoče vsebujejo načela in dejavnike znanstvenega menedžmenta ( $53 \%$ analiziranih prispevkov podpira spoznanje, da načela in dejavniki vitkega proizvajanja vsebujejo načela in dejavnike znanstvenega menedžmenta, 29 \% jih delno podpira in $18 \%$ ne podpira tega).

Organizacija: Lasnikom in vršnim menedžerjem v organizacijah bodo naše ugotovitve pomagale pri odločitvah o uvajanju načel in dejavnikov vitkega proizvajanja.

Družba: Ugotovitve iz raziskave bodo imele teoretične in praktične implikacije za vse tiste, ki se ukvarjajo z vpeljevanjem načel in dejavnikov vitkega proizvajanja iz vidika trajnostnega razvoja družbe.

Originalnost: Izvirna raziskava s področja sovpadanje načel in dejavnikov vitkega proizvajana in znanstvenega menedžmenta v Republiki Sloveniji.

Omejitve/nadaljnje raziskovanje: Integrativni pregled strokovne literature smo opravili v treh svetovnih bazah.

Ključne besede: dejavniki, podjetje, sovpadanje, vitko proizvajanje, znanstveni menedžment.

Copyright (c) Idriz SELIMOVIĆ, Mirko MARKIČ

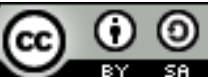

Creative Commons License

This work is licensed under a Creative Commons Attribution-ShareAlike 4.0 International License. 